\title{
A ZONE OF TWILIGHT? PEACE AND CONFLICT IN LATIN AMERICA AND THE UNITED NATIONS
}

\author{
Sezai Özçelik ${ }^{1}$
}

\section{Introduction}

Latin America is relatively one of the least conflict-ridden regions in the world. It is a relatively peaceful continent. South America has especially been one of the most peaceful places in terms of the absence of direct violence and interstate wars. There have been bilateral or trilateral conflicts between the neighbors. Most of the conflicts in Latin America is categorized under internal and intra-state conflicts. Since the 1935 Chaco War between Paraguay and Bolivia, inter-state conflicts have rarely occurred among the Latin America countries. Also, the longest interstate dispute in the world happened in Latin America between Ecuador and Peru, which started in 1809 and finished in I998. War has been the exception rather than the rule since I883 in Latin America. The last inter-state conflict in the region was the Falkland/Malvinas War between an outside power and a regional middle power, namely the Great Britain and Argentina.

The relation between peace efforts of the United Nations and international politics in Latin America today requires our attention and calls for serious reflection and study. Changes in Latin America have been remarkably rapid and widespread since the end of the Cold War. As a result, it is necessary to give scholarly attention to the explanation and understanding of conflict, peace and the role of the United Nations in Latin America. Significant continuity is also visible in the institutions, ideas, and perspectives about conflict and peace in Latin America (Özçelik 20I8). Much of the conflict in Latin America has been explained within the meaning of poverty and the proper place of poor in modern Latin America society and politics. If a scholar properly defines the poor and shed lights on the proper explanation of poverty, it becomes easier to find and solve the root causes of conflicts in Latin America (Özçelik 20I6).

In the present day of globalization and Industry 4.0 (4th Industry

I Associate Professor at Cankiri Karatekin University, Turkey.

84 
revolution), new threats and challenges generate new types of conflicts and violence. The list of current and future global threats and challenges have become longer with the end of the Cold War: Transnational terrorism, weapons of mass destruction (WMD), organized crime, global health epidemics, AIDS, population boom, drought, climate change, regional conflicts, mass migrations, environmental degradation, energy insecurity, poverty, failed states, pollution, global economic crises, human rights abuses, crimes against humanity, genocide, war crimes, etc. (Özçelik 20I9). These new threats and challenges may have a capacity to reach every corner of the world. For example, climate change may have disastrous effects on the Caribbean Island nations because they may be wiped out the world map (Özçelik 20I5). Peace and stability can be guaranteed in any state anywhere in the world, regardless of how remote and distant that international actor from the international system.

The post 9/II world has opened the Pandora's box for world affairs. International actors have been moved towards more (neo)-realist and constructivist schools of thoughts that undermines any perception of regional peace and stable future. States more likely look after their own interests, struggle for survival, and rely on self-help system. The United Nations system has weakened because international actors perceive that no state should depend on anyone else for national and international security since security threats and challenges come from new types of enemies most of which are more likely non-state and transnational. Even though many scholars believe that the importance of states has been diminishing in the international system, states may have still searched for alliances, collective security actions, and the United Nation system. Latin America as a sub-regional system has been developing as a zone of peace over the past thirty years (Oelsner 2009).

This paper aims to explain the shift in Latin America's level of conflict and internal violence relative to other regions in the world. It examines a single regional subsystem, Latin America within the framework of conflict and peace as well as the role of the United Nations. First, it aims to shed lights on main transformations and changes in terms of political, economic, social and cultural issues in Latin America. Second, the concept of the zone of peace is examined within the context of Latin America. The main activities of the United Nations in relation to conflict and peace are investigated in the third section. In conclusion, it underlines the lessons learned from conflict and peace processes in Latin America. 


\section{Main Transformations and Changes in Latin America}

Latin America has endured major changes, transformations, and shifts in the post-Cold War era. Structural changes in the region have affected many fault lines in the region. First, many scholars have been labeling Latin America as "peace zone" in terms of interstate relations. Technically, there have been rarely military inter-state conflicts in the Latin America and the Caribbean region. It is effectively called as "interstate peace zone". Latin America has also banned weapons of mass destruction (WMD) and declared itself as "denuclearized region" (Aravena 20I8). Second, democracy, the rule of law and the respect for human rights have become the important and constant norm in Latin America in the last thirty years. All the countries in the region have believed the process of democratization and opened themselves the democratic possibilities. With the third democratic wave, Latin America democracy has built some basic democratic principles such as political parties, plurality, elections and run-off rule (a second popular vote between the two leading candidates after the first round).

Election results have been mostly recognized by all political actors in the electoral system. Nevertheless, public trust to democracy has been diminishing more and more in the region. Rising disaffection among citizens of Latin America has shown as a protracted decline in political legitimacy and a negative impact on democratic co-existence (McClintock 20I8). The third major change in Latin America has been the economic transformations and economic boom. Because of global trade and neo-liberal economy, significant economic growth in Latin America has led to the reduction of extreme poverty and the growth of the middle class from 2003 to 2009 . The second decade of the twenty-first century has seen an economic slowdown and the decline of regional and global trade. Since 20I0, slow economic growth has caused the deterioration of income distribution and the rise of inequality and poverty. The governments in the region have implemented innovative policies in health and education that led to a variety of improvements in social economic indicators: access to doctors, school enrolments, infant mortality, birth rates, life expectancy, etc. in 20I0 than any year in the past (Kingstone 20II).

Another transformation in Latin America is related to the highly diverse nature of regional integration initiatives. The region has seen numerous political and economic regional integration processes. For example, the Organization of American States (OAS), the first regional organization accepted by the United Nations (UN), and the oldest regional governance system in the world, has been an important actor to tackle the most pressing security and political regional issues. The Comunidad de 
Estados Latinoamericos y Caribenos (CELAC, Community of Latin American and the Caribbean), includes every country in region consisting 33 nations, was established to provide "a common space aimed at deepening the cultural, economic, political and social integration of the region". The President of Nicaragua, Daniel Ortega, stated that "we are sentencing the Monroe Doctrine to death". Cuban President Raul Castro called CELAC "the biggest event in 200 years". Venezuelan President Hugo Chavez shouted "Viva Bolivar!" and said that "new regional group revives Bolivar's dream" (Toothaker 20II).

The last but not least development is about the overwhelming wave of transnational organized crime (narcos, cartels, paramilitaries, and street gangs), urban violence, and international migration. Although Latin America has a relative negative peace (the absence of war), transnational organized crime is today threatening the stability of many governments and causes internal conflicts and the lack of positive peace (the absence of structural and cultural violence). Transnational organized crime is also related to civilian deaths, human rights violations, human trafficking, international migration, corruption, bribery, and the collapse of social, economic and cultural structures (Carpenter 20I6).

Because of corrupt political leaders, weak institutions, and the explosion of urban violence due to drug trafficking, Latin America has seen semi-collapsed states such as completely collapsed Haiti, the brink of failure of Colombia, Mexico, and Venezuela, and instability in Guatemala, Nicaragua and the entire Andean region. The process of neo-liberal economic transformation has led to a social and cultural split in the Latin American societies. As a result, drug cartels, violent rebel organizations and paramilitary groups have caused political violence and multi-faceted conflict with multiple players, widespread use of drugs, unequal economic growth, and penetrating the culture of violence (Howard 20I6). Many extremist groups such as FARC in Colombia evolved from a Marxist-based social movement into a multimillion-dollar drug trafficking organization. The tri-border area (TBA) of Brazil, Argentina, and Paraguay has seen the rise of global terrorism in the post-September II era. For example, Hezbollah and Hamas have had "not only fundraising activities, but also arms and drug trafficking, smuggling, document and currency fraud, money laundering, and the manufacture and movement of pirated goods in this area" (US State Department 20I2).

In recent years, Bolivia, Ecuador, and Venezuela have witnessed the problems of transparency, accountability and the ability to organize opposition. In Colombia, deep-rooted, protracted and ongoing conflicts between the government and FARC have threatened the regional stability and the integrity of democratic governance. In Mexico, violent "war on drugs" and 
cartels have taken a heavy toll with more than I50,000 intentional homicides since 2006 (CNN 20I8). In almost all Latin America countries, corruption, bribery, nepotism, the lack of transparency, and human rights violations have remained as unsolved problems deteriorating stability and democracy. The rule of law has been weak and its application to the low-income citizens has been problematic.

\section{Hybrid Zone of Peace?}

Peace cannot be limited only as the absence of conflict. It is more than that. It can be divided into negative peace and positive peace. Negative peace (zone of peace) is the absence of direct violence (Özçelik 20I7). It aims to reduce, eliminate and end all physical violence as well as war. Positive peace means negative peace plus the absence of structural and cultural violence. Violence is traditionally understood as the infliction of bodily harm with the intent to hurt. Direct violence involves intentionally hurting or killing people and directed against a specific group or person. It also incorporates verbal violence (Galtung and Fischer 2013). Structural violence occurs when people can be killed, psychologically harmed, deprived or maldeveloped because of violent political or socioeconomic structures (Galtung I969). Cultural violence is the use of nationalism, racism, sexism, Islamophobia, xenophobia, and other forms of discrimination in the media, the arts, education, literature, films, street names, monuments, celebrating special national days and heroes, etc. to intellectually justify direct and structural violence (Galtung I990).

The relative security in Latin America results from legalistic and multilaterally institutionalized interactions among states and policy-makers in the region. The regional order is stable and the regular actors have regular patterns of interactions. It can be shaped by a unique Latin America identity, a shared understanding of peaceful conflict resolution, and an emphasis on growth and development. It aims to diminish the effects of great powers namely the United States and the Soviet Union in the region. Latin America's long peace can be explained with a number of factors: (I) after a first postindependence period, nation states are successfully consolidated when the border wars such as Paraguayan War (I864-1870) and the War of the Pacific (1879-1883) were settled, (2) a powerful mediatory and legalistic culture have been expanded, and (3) the independent nation-states in the region have had much higher power (Kacowicz I998). Another important factor in Latin America regional peace is the use of a tradition of peaceful resolution of 
disputes by the application of the principle uti possidetis ita possideatis ${ }^{2}$ that help to establish the shared vision of regional security governance (Kacowicz 2005).

For many scholars, Latin America is categorized as "zone of peace" in terms of the absence of interstate wars. But some scholars argue that it is a hybrid zone of peace because it is a violent place in terms of the presence of intra-city and inter-city violence, guerrillas, gang violence, youth violence, and drug traffickers that makes the highest urban violence rated region on the Earth (Merke 20II). As a region, Latin America is integrated into pluralistic international society and has a regional balance of power. Second, many conflicts related to territorial issues and natural resources have been resolved; yet, positive peace has not been achieved since structural and cultural violence has continued even if in the 2ist century. Third, both old and new regional institutions, norms, and regimes may help to find a peaceful solution to disputes and conflicts. However, organized crime and urban violence have become a real threat and challenge for regional stability and harmonized relations. Fourth, democratic peace theory can be applied to Latin America since regional democratic countries maintain sustainable development and economic interdependence that prevent wars as well as democratic institutions and public opinion constrains the policy-makers the use of force (Villa 20I7).

The idea of the zone of peace for Latin America region has come into existence not for the states within the region but for the superpowers during the Cold War. It was also based on the refusal of use of force to resolve interstate conflicts and border disputes. Many Latin American politicians and statesmen have claimed that political and economic integration and federalism may cause the denial of the use of force and common security approach in the region. For example, Simon Bolivar who is labeled as Ataturk of Latin America established Gran Colombia (present-day Venezuela, Ecuador, Colombia). The Central American societies created the United Provinces of Central America after the independence. Peru and Bolivia formed a confederated state (Mares 200I). Another reason why Latin America limits use of force is related to "hegemonic peace hypothesis" that is U.S. hegemony causes interstate peace in Latin America. Since it is considered as America's backyard, U.S. capabilities, and interests constraint the conflictual behaviors and attitudes of both international and regional actors.

2 Uti possidetis ita possideatis means "as you possess, so may you possess". Uti possidetis de jure doctrine is defined as "old administrative boundaries will become international boundaries when a political subdivision achieves independence". Paul R. Hansel, et al. "The Colonial Legacy and Border Stability: Uti Possidetis and Territorial Claims in the Americas", 2006. Available at: http://paulhensel.org/Research/ioo5.pdf. 
The hegemonic role of the US is to promote, maintain intra-regional peace in Latin America (Martin 2006). The third reason is the long tradition of using non-violent means namely mediation, arbitration and third-party intervention (especially the OAS) in Latin America conflicts. Latin Americans have made arbitration, legal institutions and international law as important components of Pax Latin Americano as well as the respect of non-intervention of foreign powers, mutual cooperation, non-interference of domestic affairs, and the peaceful settlements of disputes among the American nations (Scarfi 20I6). The fourth reason is the lack of ethnic and religious conflict in Latin America due to the homogeneity of Latin America societies. Although Latin America has suffered from ethnic and racial inequality, ethnocentric worldviews (Ögretir and Özçelik 2008), the marginalization of many indigenous people and crime-based conflicts (gang violence, drug trafficking, urban violence, and human trafficking), it still immunes from ethnic conflicts and internal violence.

\section{The United Nations in Latin America}

The United Nations has given a forum for Latin America countries. They have played a far greater role in the UN than in the League of Nations. With the increase of economic, environmental and technical organizations in the post-war era, the great powers ask for the cooperation of Latin America countries. But most of the time, Latin America states had no military and economic power to help common security in the globe. Similarly, the United Nations have very little involved to conflicts and violence in Latin America. One reason is that the United Nations have given priorities to other urgent and new violent conflicts elsewhere in the world. Second, the UN has mostly subcontracted any conflicts or crises into the United States as a regional hegemon. The U.S. has urged to take care of its "own backyard". The UN has also depended on the OAS in order to have played an active role in conflict management in the region well over seventy years (Shaw 2003).

Latin America countries have played a pivotal role in peacekeeping operations all over the world. Since Simon Bolivar, who known as the Liberator, and the Congress of Panama time, Latin American countries have participated the international organizations, supported the League of Nations, and most of them were the founding members of the United Nations in I945 (Fishel 2008). The first time when South American countries have involved in security cooperation initiative was to guarantee the League of Nations mandated peace after the Chaco War (1932-35) between Bolivia and Paraguay by the establishment of the Neutral Military Commission. The 
Latin American troops were provided by Argentina, Brazil, Chile, Peru, and Uruguay to monitor the ceasefire, to evacuate military materials and weapons, to set demarcation lines, and to supervise the exchange of prisoners of war (Neta 20I3). Uruguay lists this peacekeeping operation (PKO) as the first one for more than ninety years of PKO experience. In recent years, Latin America has evolved from peacekeeping recipients to peace exporters by increasing troop contributions by region $2,5 \%$ in 2000 to $8.9 \%$ in 2010 . Uruguay also ranked the first in Latin America and eight in the world by troop contribution with 20,394 soldiers in 2010 (Sotomayor 2015).

The first reason why Latin America countries have increased their participation in the UN PKOs is that they expect to obtain some financial gains. Second, with the rise of globalization and neo-liberalism, the Latin American societies have begun to take strong positions on global peace and security issues. Third, the wave of democratization, the desire to reform military in post-coup d'etat period, respect for human rights, the validity of international law, multilateralism, non-intervention, and peaceful conflict resolution are some overwhelming principles of the majority of Latin America population, societies and governments. Fourth, major Latin American powers such as Brazil and Argentina have evolved from realist thinking of regional power politics to neo-functionalism and neo-liberalism that advocate supranational forms of cooperation, the accommodation of domestic political agenda, regional integration and new activism in a global scale (Diamint 2013).

The contributions of Latin American states into the UN PKOs begun when Argentine and Chilean observers were sent for the deployment in the United Nations Truce Supervision Organization (UNTSO) in I948. The Chilean and Uruguayan observers were deployed in the United Nations Military Observer Group in India and Pakistan (UNMOGIP) in I949 (Kennedy 2006). Some South American states have played prominent and leading roles nearly all of the UN's PKOs during Cold War and the post-Cold War period: Brazil and Argentina contributed military personnel to the UN Operation in Congo (ONUC) between I960-64. Brazilian generals have served as a chief observer of the first UN Verification Mission in Angola (UNOVEM I) between I988-9I and as a force commander of the UN Operation in Mozambique (ONUMOZ) from February I993 to February 1994. Both Brazil and Argentina sent troops to UNAVEM I; Argentina, Brazil, and Colombia actively involved in UNAVEM II (May I99I-February I995); and Brazil and Uruguay contributed to UNAVEM III (February I995-June I997). Argentina, Brazil, and Uruguay sent troops to ONUMOZ (January I993-December I994) (Neta 20I8). Argentina has contributed two force commanders to the UN Peacekeeping Force in Cyprus (UNFICYP) and a battalion to the UN Protection Force (UNPROFOR) in 
Bosnia-Herzegovina.

The role of UN in Latin America has been disappointing during the Cold War. In order to ensure the regional conflict resolution, the U.S. proposed an idea to establish a permanent regional alliance that was set up in I947 at the Pan-American Conference held in Rio de Janeiro. The Inter-American Treaty for Reciprocal Assistance known as the Rio Treaty or Rio Pact that was heralded as the prototype of the North Atlantic Treaty Organization (NATO) in I949. The Article 3 of the Rio Treaty is similar to the famous line from the Three Musketeers, "all for themselves and none for all" that the OAS collective security mechanism (Orakhelashvili 20II): "an armed attack by any State against an American state shall be considered as an attack against all the American States". In accordance with the UN Charter article 52-54, the informal Pan-American system was evolved into a new political institution with permanent headquarter and staff: The Organization of American States (OAS).

The Charter of the OAS confirmed the equality of its member states and a guarantee of the principle of non-intervention. The OAS is in compliance with the UN Charter that re-affirm the Monroe Doctrine and the Inter-American system (Smith 2005). The most significant and major Latin American PKO was the Inter-American Peace Force that was deployed in the Dominican Republic in 1965 under the auspices of the OAS. The unilateral U.S. intervention together with the approval of I4 other OAS members aimed to end an internal conflict between the Loyalist (provisional government) and the Constitutionalist (rebel) forces. The OAS resolution was rejected only by five OAS members. Brazil, Honduras, Nicaragua, Paraguay, Costa Rica, and El Salvador have sent their troops to the mission (Wilson and Dent I995).

The UN usually involves the peaceful resolution of interstate rather than internal and intra-state conflicts. For the first time in the UN history in January 1992, the international organization played a mediator role to end the intractable and deep-rooted conflict between El Salvador government led by President Alfredo Cristiani and the guerrilla group, the Farabundo Marti National Liberation Front (FMLN). It was the first peace-building mission of the UN. The experience and involvement of $U N$ in regional peace in Latin America has been very little and rare (Whitfield 1999). The result was the establishment of the United Nations Observer Group in El Salvador (ONUSAL).

It is interesting to note that the UN's first Latin American secretary general, Javier Perez de Cuellar, has turned the UN's face more into the region as soon as he came to office in 1982 . The Contadora group was created in 1985 for promoting a political climate for peace, security and democracy in 
Latin America that was backed by the Organization of American States (OAS), the UN and the Central American governments. In order to start the peace process in Central America, the secretary-generals of the UN and the OAS visited five Central American countries in January I987. Following this visit, despite the opposition of the Reagan administration, Oscar Arias proposed a revival of the peace process in Esquipulas, Guatemala in February I987. The Esquipulas II has moved the process in the second stage in August I987 (Smith 2007).

The main transformation peace process, the Arias Plan, also aimed to reduce local conflicts and build regional security. It was drafted by the president of Costa Rica, Oscar Arias, who was awarded the Nobel Peace Prize in December I987 (Romero I998). The Arias Plan has agreed following framework to work with all conflicting parties: "regional reconciliation, political amnesty, the democratization of the region, and an end to foreign or domestic support for insurgency movements, a call for free elections, and no aggressions by one state against another" (Child I992, 48). After the signing of Central American peace agreements, the CIAV (International Commission of Support and Verification) was established with the participation of both UN and OAS in August 1989. In addition, the United Nations Observer Group in Central America (ONUCA) was approved by the UN Security Council in November 1989.The first deployment of UN peacekeeping in Latin America took effect on December I989. Its primary mandate was to monitor the Honduran-Nicaraguan border. ONUCA was commanded by the Spanish general and included 255 military observers from a dozen country and a battalion of Venezuelan para-troopers (Dent and Wilson 20I4).

ONUCA has faced some limitations and challenges. First, there was a lack of intelligence-gathering that affected ONUCA's monitoring activities. Second, the operation has logistical and administrative problems and started late. Third, ONUCA's mandate required only voluntary demobilization. As a result, it is unclear how many guerrilla forces have given up their weapons. Fourth, there is a lack of effective coordination among different institutions, namely ONUCA, UN agencies, and OAS. ONUCA also showed some innovations for the UN peacekeeping in general. First, it is the first UN peacekeeping operation with the disarmament, demobilization, and reintegration (DDR) mandate. It is also the first example to supervise elections in the sovereign nation-state. Another innovation is to combine both naval and helicopter patrols. The fourth innovation is that it is general verification and confidence building mission to monitor cross-border rebels (nearly 23,000 fighters) and weapons movement among five Central American countries. In essence, ONUCA is a success story to solve the main security issues between 
Nicaragua and Honduras (Koops 2015).

Also, there is a conflict resolution and peacekeeping model of involvement of two international organizations, the UN and the OAS in Latin America. The example was an election-observation mission for the February I990 Nicaraguan election. President Ortega called for international observers to monitor the whole electoral process for free and fair elections. The UN Security Council voted to approve the UN Observer Group for the Verification of Election in Nicaragua (ONUVEN, in Spanish). The OAS General Assembly also formally approved the OAS Observer Group to monitor the electoral process in Nicaragua in November I989 (AG/RES.993). The OAS observer team was composed of a total of 433 OAS observers that came together from the staff of the OAS General Secretariat and other agencies. In August I989, the OAS observers were disseminated into nine voting districts in Nicaragua (Beigbeder 1994).

Both ONUVEN and the OAS have exercised common authority to guarantee fair, free and successful election process and outcome in Nicaragua. Also, the Carter Center has involved in the process. In nine regions, the OAS election offices that were staffed by two persons listened to complaints about the elections. Their works focused on observing registration process and incidents of intimidation in different parts of the country. At the end of the process, several hundred complaints were received, most of which are related to voter registration procedures, election rules, media issues, and campaign activities. One example was free and fair access to the media (Pallister 20I7). The state-run TV created an opportunity for all political parties to air their views. But broadcasts did not reach the whole country. The TV staff who were allegedly Sandinista sympathizers intimidated the UN staff who worked to solve the problem. After the direct intervention of Ortega and the head of the Supreme Electoral Council, the UN representatives were able to correct the TV broadcasting (Orozco 2002).

\section{Final Remarks}

The conflicts during the Cold War in Latin America have been characterized by a series of overlapping conflicts. They can be explained within four interrelated issues. First, the perpetual clash over domestic arrangements and internal power structures have produced cycles of repression, resistance, and instability. Second, the U.S. power in Latin America has caused the persisting tension about the nature of inter-American relations. Third, the emergence of North/South divide and the Third World has given birth to social tension and ideological split in the society. Fourth, two superpowers, 
the U.S. and the Soviet Union, have played a zero-sum game in the global South to achieve political, strategic and ideological hegemony (Brands 20I0).

It is necessary to summarize the reasons for the hybrid zone of peace in Latin America. First, the United States as a global hegemon and Brazil as a regional hegemon have played a balancer role to counter external threats towards the region. Second, two regional balance of power eras, I883-I930 and I970-80, have been crucial for the maintenance of regional peace. Third, the idea of Bolivarianism believes that a loose confederation among the Central and South American countries prevent external threats. In order to inhibit first European then U.S. threat of intervention, many Latin American countries have settled their conflicts and border disputes within the principle of non-intervention and peaceful settlement of the dispute. Fourth, a regional balance of power among Brazil, Argentina, Chile and Peru, Pax Brasiliana or Pax Americana, is caused by the geographic isolation, the lack of interaction, economic and political irrelevance, and weak military powers and underdeveloped economies.

Fifth, the trend of democratization in the early I980s and the transition from authoritarian to liberal/democratic regimes in Latin America has explained the low level of international conflicts and high level of political stability and normative consensus on stable peace. Sixth, there is an empirical link between the economic development, growth, and prosperity and neoliberal economic transformations with the Chicago Boys and the absence of wars. Although dependence theories may shed light on the lack of economic development in Latin America, the pursuit of economic growth with neoliberalism may have a pacifying effect in the region. Seventh, economic interdependence, the institutionalization of mutual cooperation, and regional integration such as MERCOSUR and the Andean Pact are important forces for regional peace. Eighth, the reason why the use of force is absent in Latin America's international relations is related to diplomatic culture, common historical and cultural backgrounds, distinctive regional solidarity and identity, and exceptionalism about a peaceful settlement of international disputes via arbitration, mediation, bilateral negotiations, and third party interventions. Ninth, Latin Americans are satisfied with the territorial status quo because the principle of uti possidetis has become a rule after regional wars during the last decades of I 1 th and the first two decades of 20 th centuries (Kacowicz 2005).

It is important to highlight the lessons learned from the peace process in Latin America. First, after prolonged negotiations and third-party interventions, the guerrillas are going from freedom fighters or terrorists to the political players in the democratic process. We have also learned that 
negotiating and signing a peace agreement is the onlythe first step. The most important thing is the commitment, fulfillment, and implementation of the peace treaty, namely post-conflict peace-building, and post-conflict reconstruction not only short-term political and economic stabilization but also long-term state recovery and positive peace. Second, successful transition to peace in Latin America requires the DDR involves the elimination of post-conflict security challenge by the reintegration and the resettlement of displaced persons in order to end violent conflict. The peace in Latin America needs to have a process of reinforcing mutual confidence and financial support for the open and inclusive state. Third, Latin America countries such as Southern Cone (Argentina, Brazil, Uruguay, and Paraguay) have experienced transitions from military dictatorship to democracy as well as political, economic and social structures. Fourth, another transition in Central America (El Salvador, Guatemala, Honduras, Nicaragua, and Panama) is to end revolutionary movements by laying down arms and building more open and democratic societies.

The post-Cold War Latin America has seen the end of the following internal conflicts: The Zapatista in Chiapas Mexico, Shining Path (Sendero Luminoso) and Tupac Amaru Movement in Peru, the Sandinistas in Nicaragua, the URNG (La Unidad Revolucionaria Nacional Guatemalteca) in Guatemala, and the FMLN (Farabundo Marti para la Liberacion Nacional) in El Salvador (Colletta 2000). Fifth, ethnic rivalries and religious conflict are not common in Latin America unlike regions of sub-Saharan Africa, the Middle East, and Southeast Asia. Because most of the internal conflicts have caused by proxy wars of the bipolar international system, the stability and peace mostly depended on external factors and actors (Özçelik 20I8). When the Cold War was ended, international actors such as the UN have played an essential role to sustain stability and support peace processes, especially in the Central America. Conflict resolution and peace-building in Latin America have required bringing together conflicting parties by using neutral facilitating and mediating role of international actors such as the UN and the regional power brokers such as Costa Rican President Oscar Arias Sanchez.

Latin America has had a unique regional conflict management approach in accordance with the United Nations. Most regions in the world have not used legal peace-making approaches and institutions. But Latin America countries often resort to international arbitration to find a solution for their territorial disputes. Second, the region has mostly applied economic sanctions not as symbolic actions such as Arab states boycott of Israel and Organization of African Union (OAU) sanctions against apartheid South Africa but main tools to force the conflicting parties to meet in the table for negotiation and 
mediation (Diehl 2003). Third, non-governmental organizations such as the Amnesty International, International Crisis Group, the Carter Center, the Centre for Humanitarian Dialogue in Switzerland has increasingly been used in various aspects of conflict resolution such as critical services, humanitarian relief, refugee resettlement, infrastructure development, grassroots activities, and coordinating citizen diplomacy. Also, training activities aim direct action, skills transfer, and institution building. Insider partial third party intervention promotes cooperative relationships with local actors and combines with local peace-making traditions and modern conflict resolution tools (Bercovitch and Jackson 2009).

If we look back the last 200 years of history in Latin America, we can conclude that the first Ioo years have seen the independence of the region and relatively many inter-state conflicts and border disputes. But the last roo years have witnessed the lack of war and the relative long peace. The security and conflict problems have mostly taken care of by the inter-American regional organization, the OAS. There have been some successful and some failed attempts to address security, economic, social and cultural issues through regional and sub-regional organizations: the Community of Andean Nations (CAN), Bolivian Alternative for Our Americas (ALBA, meaning "dawn" in Spanish), Union of South American States (UNASUR), Community of Latin American and Caribbean States (CELAC), MERCOSUR (Southern Common Market), Free Trade of Areas of Americas (FTAA), Central American Common Market (CACM), etc. These new regional institutions have shown that the unipolar U.S. dominance has been diminishing and multi-polarity and the influence of other international actors (the EU and China) has been growing in the first decade of the 2Ist century. Regional organizations in Latin America are everywhere and multiplied with overlapping functions and segmenting territories. However, this does not lead to supra-national institutions like the EU or technocratic elites like the EU technocrat. Although territorial boundary conflicts are rare in Latin America, there is still a possibility that maritime borders become more prominent in terms of geo-economics interests and natural resources (Malamud and Schenoni 20I6).

The United Nations have helped Latin America countries to reach positive peace, namely economic growth and transformation as well as sustainable development. With the help and support of the UN agencies such as the United Nations Development Programme (UNDP), World Food Programme (WFP), United Nations Children Fund (UNICEF), United Nations Populations Fund (UNFPA), and the United Nations Environmental Programme (UNEP), Latin America countries have improved their basic nutrition, primary education, preventative health care, the promotion of 
gender equality, and the preservation of natural environments. The UN has played a vital role in global and regional environmental problems in Latin America in the last decade. Since the Amazon region is very important for global climate change, the UN initiatives have focused on the reduction of air pollution in big Latin American cities and the promotion of the use of renewable energies. The UNEP which specifically established to support the combating global environmental threats has also implemented regional programs on land use planning, forest management, protection of fresh water and marine resources, the strengthening of public sector capacity, the training of government officials, and the improvement of environmental regulations and laws (Adams 20I0). In the long term, the UN has helped each Latin America nation to use more effectively its resources, to meet human needs, to have fewer public health problems, to raise attendance and performance of children in school and to increase the productivity and capacity of adults in the workplace.

It is necessary to emphasize that South America countries have increased their contribution and participation of collective security measures, namely the United Nations peace-keeping operations (PKOs). The first important factor about South America's common and shared peacekeeping culture is the strong normative elements on broad defense and foreign policy and the policy coordination of peacekeeping operations (Kenkel 2013). As the Cold War ended in Europe almost without any major conflicts and superpower cooperation on conflict resolution and peacebuilding has risen into all-time high, the United Nations have effectively been undertaken peaceful resolution of regional conflicts in Latin America region. Likewise, the UN Secretary Generals have sent at the right place at the right time for good office missions. For example, Javier Perez de Cuellar's individual abilities have been effective the resolution of Central America's peace process. Similarly, Boutros BoutrosGhali has involved 75 good office and fact-finding missions and visited 23 states including some Latin America countries. In addition, special representatives of the UN Secretary General such as Jean Arnault and Alvaro de Sato have performed important roles to mediate peace settlements in Guatemala and El Salvador. In addition to UN organs such as the Security Council and the Secretary General, regional bodies and organizations such as the OAS and other Latin America regional organizations have been used within the explicit mandate the UN Charter to help their members to peacefully find resolution their conflicts. Also, groups of states have formed loose ad hoc groupings for the objective of providing diplomatic assistance for peaceful solutions of conflicts between or within other states under the UN auspices. For example, the UN has become a peace broker via help of the Contadora group which was 
formed by the foreign ministers of a number of Central and Latin American states (Wilson 20I4).

In Latin America, the UN has had a mixed record to succeed in finding peaceful resolutions of conflicts that threatened regional peace and security. The success of the UN diplomatic efforts in Latin America is mostly depended on the existence of conducive political circumstances to facilitate the dispute settlement. Under the UN Charter Chapter VII, the Security Council can be effective only if the conflicting parties are willing to submit themselves fully the possibility of peaceful settlement. Moreover, the UN collective security system has evolved into more robust and creative measures especially during the 2ist century in Latin America.

\section{REFERENCES}

Adams, Francis. 2010. The United Nations in Latin America: Aiding Development, New York: Routledge.

Aravena, F. Rojas. 20I8. Peace and Security in Latin America: New Challenges, New Directions. Ursula O. Spring and Serena E.S.

Oswald (eds.), Risk, Violence, Security, and Peace in Latin America: 40 Years of the Latin America Council of Peace Research (CLAIP), Switzerland: Springer, 59-60.

Beigbeder, Yves. I994. International Monitoring of Plebiscites, Referanda and National Elections: Self Determination and Transition to Democracy, Netherlands: Martinus Nijhofff Publishers.

Bercovitch, Jacob and Richard Jackson. 2009. Conflict Resolution in the Twentyfirst Century: Principles, Methods, and Approaches, An Arbor, MI: University of Michigan Press.

Brands, Hal. 2oro. Latin America's Cold War. Cambridge, MA: Harvard University Press.

Carpenter, Ami C. 20I6. "Gang Conflict and Drug Trafficking: Challenges and Opportunities for Conflict Resolution in Mexico and Central America”, Kirsten Howarth and Jenny H. Peterson (eds.), Linking Political Violence and Crime in Latin America, Lanham, MD: Lexington Books,20I6, 27-5I.

Child, Jack. I992. The Central American Peace Processes, I983-I99I: Sheathing Swords, Building Confidence, Boulder: Lynne Rienner.

CNN. 20I8. "Mexico Drug War Fast Facts". CNN, July I6, 20I8. https:// edition.cnn.com/2013/09/02/world/americas/mexico-drug-war-fast- 
facts/index.html

Colletta, Nat et.al. 2000. "Toward an Architecture for Sustainable Peace and Development: Lessons from the World Bank's Experience”, Andres Solimano (ed.), Colombia: Essays on Conflict, Peace, and Development, Washington D.C.: World Bank, 2000, pp. I59-182.

Dent, David W. and Larman C. Wilson. 20I4. Historical Dictionary of InterAmerican Organizations, Lanham: Scarecrow Press.

Diamint, Rut. 2013. "From Fear to Humanitarianism: Changing Pattern in Argentina's Involvement in Peace Operations", Kai Michael Kenkel (ed.), South America and Peace Operations: Coming of Age, New York: Routledge, pp. I32-I50.

Diehl, Paul F. 2003. "Conclusion: Patterns and Discontinuities in Regional Conflict Management", Paul F. Diehl and Joseph Lepgold (eds.), Regional Conflict Management, Lanham: Rowman and Littlefield Publishers, 2003, pp. 269-28I.

Fishel, John T. 2008. "Latin America: Haiti and Beyond”, Donald C.F. Daniel et al., Peace Operations: Trends, Progress, and Prospects, Washington D.C.: Georgetown University Press, pp. I53-167.

Galtung, Johan. I969. "Violence, Peace, and Peace Research", Journal of Peace Research, 6, no. 3, I969, pp. I67-I9I.

Galtung, Johan. I990. "Cultural Violence”, The Journal of Peace Research, 27(3), I990, pp. 29I-305.

Galtung, Johan and Dietrich Fischer. 2013. Johan Galtung: The Pioneer of Peace Research, Dordrecht: Springer, 2013.

Hansel, Paul R. et al. 2006. The Colonial Legacy and Border Stability: Uti Possidetis and Territorial Claims in the Americas. Online, available at: http://paulhensel.org/Research/ioo5.pdf

Howard, Tiffiany. 20I6. Failed States and the Origins of Violence: A Comparative Analysis of State Failure as a Root Cause of Terrorism and Political Violence, New York: Routledge.

Kacowicz, Arie M. I998. Zone of Peace in the Third World: South America and West Africa in Comparative Perspective, Albany, NY: SUNY Press.

Kacowicz. Arie M. 2005. The Impact of Norms in International Society: The Latin America Experience, I88I-200I, Notre Dame, IN: University of North Dame Press.

Kenkel, Kai Michael. 2013. “Conclusions: Securing South America's Peace Operations acquis post-MINUSTAH”, Kai Michael Kenkel (ed.), South America and Peace Operations: Coming of Age, New York: Routledge, 
pp. I88-20I.

Kennedy, Paul. 2006. The Parliament of Man: The Past, Present, and Future of the United Nations, New York: Random House.

Kingstone, Peter. 20II. The Political Economy of Latin America: Reflections on Latin America: Reflections on Neoliberalism and Development, New York: Routledge.

Koops, Joachim A. 2015. “United Nations Observer Group in Central America (ONUCA)”, Joachim A. Koops et al., The Oxford Handbook of United Nations Peacekeeping Operations, Oxford: Oxford University Press, pp. 306-313.

Malamud, Andres and Luis L. Schenoni. 20I6. "Neoliberal Institutionalism and Neofunctionalism in Latin American Security Studies", David R. Mares and Arie M. Kacowicz (eds.), Routledge Handbook of Latin American Security, New York: Routledge, pp. 44-56.

Marcondes de Souza Neta, Danilo. 2013. "Regional Defense Integration and Peacekeeping Cooperation in the Southern Cone", Kai Michael Kenkel (ed.), South America and Peace Operations: Coming of Age, New York: Routledge, pp. 64-8I.

Marcondes de Souza Neta, Danilo 20I8. "A Renewed Partnerhsip?: Contemporary Latin America-Africa Engagement”, Dawn Nagar and Charles Mutasa (eds.), Africa and the World: Bilateral and Multilateral International Diplomacy, New York: Palgrave MacMillan, 2018, pp. 209-244.

Mares, David R. 200I. Violent Peace: Militarized Interstate Bargaining in Latin America, New York: Colombia University Press.

Martin, F. E. 2006. Militarist Peace in Latin America: Conditions for War and Peace, New York: Palgrave.

McClintock, Cynthia. 20I8. Electoral Rules and Democracy in Latin America, Oxford: Oxford University Press.

Merke, Federico. 20II. "The Primary Institutions of the Latin American Regional Interstate Society", Paper Presented at the IDEAS Latin America Programme, LSE, London. Thursday, January 27, 20II. http://repositorio.udesa.edu. ar/jspui/bitstream/ I o 908/488/I/\%5bP\%5d\%5bW\%5d\%20 DTiıFedericoMerke.pdf

Oelsner, Andrea. 2009. International Relations in Latin America: Peace and Security in the Southern Cone, New York: Routledge.

Orakhelashvili, Alexander. 2orı. Collective Security, Oxford: Oxford University Press. 
Orozco, Manuel. 2002. International Norms and Mobilization for Democracy: Nicaragua in the World, New York: Routledge.

Ögretir-Özçelik, Ayse Dilek. 20I7. “Aggression Theories Revisited: Lorenz's Instinctivism, Wilson's Socio-biology, and Skinner's Behavioral Theories, Journal of Asian Scientific Research, vol. 7, no.2, 20I7, 38-45. http://www.aessweb.com/pdf-files/JASR-20I7-7(2)-38-45.pdf

Ögretir-Özçelik, Ayse Dilek. 20I7. "Explanation and Understanding of Human Aggression: Freudian Psychoanalytical Analysis, Fromm's Neo-Freudian Perspectives, and Bandura's Social Learning Theory", International Journal of Social Science and Economic Research, vol. 2, no.I, January 20I7, 2I5I-2I64. http://www.ijsser.org/uploads/ ijsser_02__I33.pdf

Ögretir, Ayse Dilek and Sezai Özçelik. 2008. “The Study of Ethnocentrism, Stereotype, and Prejudice: Psycho-analytical and Psycho-dynamic Theories", Journal of Qafqaz University, vol. 24, Fall 2008, pp. 236244 .

Özçelik, Sezai. 20ı8. "Latin Amerika Çatısmaları ve Analizleri”, Ismail Ermagan (ed.), Dünya Sipasetinde Latin Amerika 2, Ankara: Nobel Yayınevi, 27I-295.

Özçelik, Sezai. 20ı6. "Latin Amerika ve Ortadogu: Benzerlikler ve Farklılıklar”, Yeni Türkiye: Ortadogu Özel Say1s1-I, say1 82, y1l 22, Ocak-Haziran 2016, 306-315.

Özçelik, Sezai. 2oI9. "Introduction”, Nejat Dogan (eds.), International Security, Eskisehir: Anadolu University Publication, 20I9, p. 23.

Özçelik, Sezai.20I5. "Climate Change Negotiations Positions of the United States, the European Union, and the G-77 before and after the Kyoto Protocol: I995-2002", Enerji ve Diplomasi Dergisi, vol. I, no.I, issue 2, 20I5, 34-60.

Özçelik, Sezai. 2oı8. "The Cold War Re-visited: Explaining and Understanding of the End of the Cold War", The Turkish Yearbook of International Relations, vol. 49 (I), 20I8, pp. I-20. http://dergiler.ankara.edu.tr/ dergiler/44/2259/23496.pdf

Pallister, Kevin. 20I7. Election Administration and the Politics of Voter Access, New York: Routledge.

Romero, Carlos A. 1998. "Exporting Peace by Other Means: Venezuela", Jorge I. Dominguez (ed.), International Security and Democracy: Latin America and the Caribbean in the Post-Cold War Era, Pittsburg, PA: University of Pittsburgy Press, pp. I5I-I66. 
Scarfi, Juan Pablo. 20i6. "In the Name of the Americas: The Pan-American Redefinition of the Montroe Doctine the Emerging Language of American International Law In the Western Hemisphere, I898I933", Diplomatic History, 40, vol. 40, issue 2, April 20I6, p. I89-2I8.

Shaw, Carolyn M. 2003. "Conflict Management in Latin America”, Paul F. Diehl and Joseph Lepgold (eds.), Regional Conflict Management, Lanham: Rowman and Littlefield Publishers, pp. I23-152.

Smith, Joseph. 2005. The United States and Latin America: A History of American Diplomacy, I776-2000, New York: Routledge.

Smith, Joseph. 2007. Historical Dictionary of United States-Latin American Relations, Lanham, MD: The Scarecrow Press.

Sotomayor, Arturo. 2015. "Latin America's Experience with Peace Support Operations: From Peacekeeping Recipients to Peace Exporters", David R. Mares and Arie M. Kacowicz (eds.), Routledge Handbook of Latin American Security, New York: Routledge, p. 324-335.

US State Department, Office of the Coordinator for Counterterrorism. 2012. Country Report on Terrorism 20II, July 2012; Matthew Levitt, "South of the Border, A Threat from Hezbollah", The Journal of International Security Affairs. https://www.washingtoninstitute.org/uploads/ Documents/opeds/Levitt201305I5-JISA.pdf

Toothaker, Christopher. 20II. “Chavez: New Regional Group Revive Bolivar's dream", The Associate Press, December 02, 20II. https://www. nytimes.com/20II/I2/03/world/americas/venezuela-new-regionalgroup-meets.html

Villa, Rafael D. 20I7. "Security Community or Balance of Power?: Hybrid Security Governance in Latin America”, Marcial A.G. Suarez et al., Power Dynamics and Regional Security in Latin America, New York: Palgrave MacMillan, pp. 77-Ioo.

Whitfield, Teresa. I999. "The Role of the United Nations in El Salvador and Guatemala: A Preliminary Comparison", Cynthia Arnson (ed.), Comparative Peace Processes in Latin America, Standford, CA: Standford University Press, pp. 257-290.

Wilson, Gary. 20I4. The United Nations and Collective Security, New York: Routledge.

Wilson, Larman C. and David W. Dent. I995. "The United States and the OAS”, David W. Dent (ed.), U.S.-Latin American Policymaking: A Reference Handbook, Westport, CT: Greenwood Press, pp. 24-44. 


\section{ABSTRACT}

This paper aims to explain the shift in Latin America's level of conflict and internal violence relative to other regions in the world. It examines a single regional subsystem, Latin America within the framework of conflict and peace as well as the role of the United Nations. First, it aims to shed lights on main transformations and changes in terms of political, economic, social and cultural issues in Latin America. Second, the concept of the zone of peace is examined within the context of Latin America. The main activities of the United Nations in relation to conflict and peace are investigated in the third section. In conclusion, it underlines the lessons learned from conflict and peace processes in Latin America.

\section{KEYWORDS}

Peace; Conflict; Latin America; United Nations; Zone of Peace.

Received on July 07, 2020

Approved on March 08, 2021 